\title{
Post-conflict development in Liberia: Governance, security, capacity building and a developmental approach
}

\section{Edward Banka Gariba*}

\begin{abstract}
This article examines the causes of the Liberian Civil War of 1989-2003, and proposes policy alternatives that the current government can pursue to ensure durable peace and development. The paper argues that bad governance accounted for the conflict. Therefore, if peace, security and development are to be attained, there is a need for the current government to adopt and implement four policy options: good governance, security sector reform, a long-term development approach, and capacity building at the national and local levels. Although the new President of Liberia has taken some critical steps towards implementing some of these policies, more work needs to be done to address
\end{abstract}

* Edward Banka Gariba is a Ph.D. student in Health Policy at McMaster University, Canada. Gariba has obtained a Master's degree in Political Science with a specialisation in International Relations and Comparative Politics from Brock University, Canada. He has another Master's degree in Public Policy and Administration from Carleton University, Canada, in Ottawa, and a Bachelor's degree in Political Science from the University of Ghana in Accra. His research interests are focused on health policy, governance, poverty reduction and food security, and evaluating post-conflict peacebuilding and reconstruction projects. 


\section{Edward Banka Gariba}

corruption, and promote transparency, accountability, good governance and development if a relapse into conflict is to be avoided.

\section{Introduction}

Post-conflict development/peacebuilding ${ }^{1}$ requires all measures that are necessary to help a country move from conflict to sustainable peace. Concerns about the best approaches and policy options available in post-conflict countries to ensure both sustainable peace and development have been the preoccupation of policy makers and development practitioners. Scholars in peace studies and democratic governance have been concerned about whether post-conflict development should be focused on the provision of short-term humanitarian assistance and rehabilitation, and the holding of early elections, or should be anchored in long-term development. Policy makers in war-torn societies should also be concerned about how to deal with ex-combatants and security issues in order to ensure durable peace and economic development for the people.

Following the election of Ellen Johnson Sirleaf as the President of Liberia in 2005, peace has gradually returned to the country. The issue of most importance to policy makers now is how to maintain a durable peace in the country. This article seeks to explore three research questions. Firstly, what political governance and security policies are needed to enable a country like Liberia that has just come out of war to rebuild itself and prevent a relapse into conflict? Secondly, should post-conflict development/peacebuilding be a short-term or long-term development goal? Finally, how should a long-term development goal which includes capacity building at the national level and for local communities be pursued in Liberia?

This article seeks to examine governance and security policies that are needed to help the country achieve durable peace and sustainable development. With regard to political governance, it is argued that there is a need to pursue good governance (political inclusiveness) to ensure balanced representation of the

1 The terms 'post-conflict development' and 'peacebuilding' are used here interchangeably. They refer to measures and structures put in place to build lasting peace and socioeconomic and political development in post-conflict societies. 
various regional and ethnic groups. In terms of security policy, four policy options are argued and recommended. The first includes the disarmament, demobilisation and reintegration (DDR) of former combatants into the civilian population. The second is to develop national security and defence policy. The third is to regionalise effective police collaboration with customs officers, which is necessary for controlling cross border proliferation of small and light weapons. Fourthly, a professional army needs to be established. Finally, it is argued that post-conflict peacebuilding requires long-term development goals, including capacity building at the national level and within local communities.

There were several factors that led to the choice of Liberia for this study. Liberia has just returned to democratic rule after long years of violent conflict. The first period of conflict, in 1989-1999, was followed by more violent conflict in 1999 to 2003. There have been two interregnums in government administration. The first was from 1990 to 1996 when Dr. Sawyer acted as interim president, until the 1997 elections where he handed over power to Charles Taylor. The second was from 2003 to 2005 where Gyude Bryant acted as interim president until January 2005 when Ellen Johnson Sirleaf was elected. It is, therefore, worth investigating the following questions: What factors led to the crisis in Liberia after the 1997 election? What policies are needed to maintain durable peace in Liberia, so that it does not relapse into violent conflict following the election of Ellen Johnson Sirleaf to power?

This article is organised in five parts. The first part offers a brief review of the literature on post-conflict development/peacebuilding. This is followed by an examination of the background to the Liberian Civil War. The third part discusses political inclusiveness (good governance) as a measure against renewed conflict, whilst the fourth section offers security policies needed to promote durable peace and sustainable development. Finally, a long-term development approach to peacebuilding including capacity building for local communities in Liberia is discussed. 


\section{Theoretical framework: Post-conflict development/ peacebuilding}

The most urgent challenge faced by the international community and humanitarian relief agencies involved in post-conflict development/ peacebuilding has been to find the most appropriate way of putting in place measures to ensure durable peace without a relapse into conflict. Indeed, traditional peacekeeping operations, which were implemented between the end of the Second World War and the end of the Cold War, required peacekeepers to create a buffer zone to separate warring or belligerent parties and prevent them, through their mutual consent, from fighting. Thus traditional or first generation peacekeeping operates according to three principles: consent of the parties to the conflict, impartiality of peacekeepers and minimum use of force (Donald 2002:21). However, with the end of the Cold War, many conflicts emerged in the global system that led to the escalation of violence and human casualties. Prompted by the need to protect human rights, UN Secretary-General, Boutros Boutros-Ghali, proposed a 'second generation' of UN peace operations in which the mandate of peacekeeping was extended to the deployment of large UN peacekeeping forces, the protection of human rights and the permission to use force (Boutros-Ghali 1995:4; Slim 1996:6)). In this type of peacekeeping operation, peacekeepers are actively involved in the resolving and settling of conflicts - in the cases of both inter- and intra-state conflicts (Williams 1998:1; Richmond 2002:44).

Peacebuilding, as a concept introduced by Boutros Boutros-Ghali in his Agenda for Peace, involves three components: preventive diplomacy, peacemaking and peacekeeping (Boutros-Ghali 1992). He (Boutros-Ghali 1992: par 21) defines peacebuilding as 'action taken to identify and support structures which will tend to strengthen and consolidate peace in order to avoid a relapse into conflict'. For Boutros-Ghali, a comprehensive multidimensional peacekeeping undertaking is inseparable from peacebuilding. For him, comprehensive peacekeeping includes:

The supervision of ceasefires, the regroupment and demobilization of forces, their reintegration into the civilian life and the destruction of their weapons; the design and implementation of de-mining programmes, the 
return of refugees and displaced persons; the provision of humanitarian assistance; the supervision of existing administrative structures, the establishment of new police forces; the design and supervision of the constitutional, judicial and electoral reforms, the observation, supervision and even organization and conduct of elections and the coordination of support for economic rehabilitation and reconstruction (Boutros-Ghali 1995:6).

In the same vein, UN Secretary-General Kofi Annan proposed an integrated post-conflict peacebuilding approach. He argued that:

By post-conflict peace-building, I mean actions undertaken at the end of a conflict to consolidate peace and prevent a recurrence of armed confrontation. Experience has shown that the consolidation of peace in the aftermath of conflict requires more than purely diplomatic and military action, and that an integrated peace-building effort is needed to address the various factors that have caused or are threatening a conflict. ... It aims rather to build on, add to, or reorient such activities in ways designed to reduce the risk of a resumption of conflict and contribute to creating the conditions most conducive to reconciliation, reconstruction and recovery (United Nations 1998).

Kenneth Bush (1996:76) also argues that post-conflict development entails short-term humanitarian operations and long-term developmental objectives:

In the broadest term, peacebuilding refers to those initiatives which foster and support sustainable structures and processes for peaceful coexistence and decrease the likelihood of the outbreak, reoccurrence, or continuation, of violent conflict. The process entails both short- and long-term objectives, for example, short-term humanitarian operations and longer-term developmental, political, economic and social objectives.

While there appears to be a general consensus of what peacebuilding involves, there has been a lack of commitment by the international community to long-term development goals. Rather, peacekeeping operations are seen as a 


\section{Edward Banka Gariba}

short-term development goal or a subset of military operations rather than a long-term development one. In Kenneth Bush's view, the international community's approach to peacebuilding, which is based on 'quick in-and-out operations', is tantamount to 'bungee cord humanitarianism' (Bush 1996:76). This means interventions that merely show presence without addressing the problems. In other words, there is a gap between rhetoric and action on the part of the international community in peacebuilding.

A development scholar, Peter Uvin, views post-conflict development/peacebuilding as premised on three pillars: rehabilitation, reconstruction and development (Uvin 2000:9). James Busumtwi-Sam (2004:317; White and Cliffe 2000) note the same three distinct approaches to post-conflict development along the continuum of humanitarian assistance, rehabilitation and conventional development. They all acknowledge the utility of humanitarian assistance/relief, rehabilitation and development approaches in providing short- to medium-term needs of individuals, refugees' resettlement, shelter, food and medical attention in post-conflict societies, but they also admit of their shortcomings. For instance, Peter Uvin notes that there has been a lack of financial commitment by the international community towards post-conflict development. As he argues, 'the international community is not willing to or capable of providing the resources of creating a truly functioning democracy' (Uvin 2000:11).

Busumtwi-Sam (2004:340-345) also notes the problems of post-conflict development to include a lack of third window financing, slow responses to peacebuilding (post-conflict development); the gap in making a pledge and making a commitment of financial support, and a lack of sustained commitment where donors tend to disengage once a conflict has receded from public attention.

Another important limitation in post-conflict peacebuilding, as noted by Chesterman and Reilly, has been the rush to hold early elections and exit the war-torn country without putting in proper security policies or addressing the root causes of the conflict (Chesterman 2002:207-209; Reilly 2002:120). In this regard, merely rehabilitating the state and pursuing development policies without addressing the root causes of conflict and security issues cannot bring lasting peace. As Green and Ahmed (2004:319) argue, 'peacebuilding involves the 


\section{Liberia: Governance, security, capacity building and a developmental approach}

fundamental questions not only about what to reconstruct but also about how to do so in order not to recreate the unsustainable institutions and structures that originally contributed to the conflict'. Thus, post-conflict reconstruction projects or policies need to, and should, address the underlying causes of the conflict, by dislodging the institutions and structures that caused it and creating new strong institutions and structures that can contribute to a sustainable peace.

The three approaches, humanitarian assistance, rehabilitation and a short-term development goal, though necessary, have a lot of weaknesses. Humanitarian assistance is needed to provide shelter, food, clothing and medicine to victims of conflict. This is crucial because securing the lives of the people in anticipation of constructing democracy and the rule of law is of utmost importance in a post-conflict society. Rehabilitation, which concerns immediate tasks that must be undertaken after the cessation of violence to restore a basic semblance of normality and restore the basic functioning of the state, usually takes three to six months (Uvin 2000). Thus rehabilitation seeks to provide physical infrastructure for the reintegration of refugees and internally displaced persons. Thirdly, a short-term development approach aims at reconstructing the state by providing temporary shelter, drafting a constitution and putting in place administrative structures. But such measures fail to address long-term development issues.

This article intends to address the above limitations or fill in some of the gaps in the approaches to post-conflict development, especially by addressing the root causes of conflict, and showing how to maintain effective security policies that will prevent a return of conflict. Thus, it argues that post-conflict development requires four approaches: good governance (addressing the root causes of the conflict and establishing inclusive governance), security reforms, a long-term development goal, and building local capacities. These four approaches have either been missing or have not been integrated into peacebuilding or postconflict development literature. Rather, the emphasis has been on humanitarian assistance, rehabilitation and short-term development goals. This article seeks to contribute to the existing knowledge on post-conflict development, by adopting a holistic and an integrative approach in which long-term development goals, capacity building, good governance and security reforms are brought together 


\section{Edward Banka Gariba}

to be viewed properly and subsequently addressed. That way, the search for peace in Liberia, as in any post-conflict country, may be guaranteed.

\section{Interrogating the causes of conflict in Liberia}

To examine the causes of the conflict in Liberia, a brief background of the country's civil war is needed. The Liberian civil war began in 1989. The country was ruled by Americo-Liberians (American descendants) until 1980 when Sergeant Samuel Doe, a native Liberian, became the first president of Liberia. Liberians for the first time thought they were going to be liberated under Samuel Doe's regime. However, his regime became very authoritarian, discriminatory and abusive of human rights in Liberia. It was as a result of the repressive regime of Samuel Doe that Charles Taylor began an attack in 1989 which finally led to the overthrow of Samuel Doe's government by a break-away faction from the rebels' group of Charles Taylor. This group, known as the Independent National Patriotic Front of Liberia (INPFL), was led by Prince Johnson in September 1990. The ECOWAS Monitoring Group (ECOMOG), a regional peacekeeping group of the Economic Community of West African States (ECOWAS), mediated, and Dr. Sawyer acted as interim president until the 1997 elections when Charles Taylor of the National Patriotic Front of Liberia (NPFL) was elected as president. Two years later, the civil war began with two rebel groups. One emerged from the border between Ivory Coast and Liberia and became known as the Movement for Democracy in Liberia (MODEL), the other was started by a group of exiled Liberians in Guinea who called themselves Liberians United for Reconciliation and Democracy (LURD).

These two groups that fought Taylor's government destabilised the country. With international pressures and ECOWAS intervention, Charles Taylor was compelled to resign in 2003. He went into exile in Nigeria and his vice-president, Gyude Bryant, was chosen to act as interim president until the 2005 election, when Ellen Johnson Sirleaf was elected and sworn in as the President of Liberia in January 2006.

Given this background of the civil war in Liberia, the questions that need to be asked are: What led to a resumption of conflict following the end of the 
war in 1990 and the election of Charles Taylor as president of Liberia in 1997 ? Were the root causes of the conflicts that led to the first civil war from 1989 to 1990 addressed? If they were not, what lessons can be learned by the present government of Liberia in this post-conflict period, and what policies are needed to maintain peace and stability in Liberia without a resumption of conflict?

Many reasons have been given for this conflict. For Adebajo, the conflict is generally attributed to bad governance. Adebajo identifies six key issues, as indices of bad governance, that contributed to the Liberian War: 'the exclusionary rule of the Americo-Liberian Oligarchy, the brutal and inept rule of Samuel Doe; the deleterious effects that Doe's rule had on the armed forces of Liberia, ethnic rivalries and personal ambitions that resulted from Doe's rise to bloody power; and the destabilizing effects of the withdrawal of the U.S. support from Doe, a strategic Cold War ally' (Adebajo 2002:19).

Given these issues outlined by Adebajo, it can be seen that Liberians suffered from the Americo-Liberian rule in that they were systematically discriminated against in terms of employment, political representation and development projects. But did the situation change when Samuel Doe, a native Liberian, gained power in 1980? It did not. Samuel Doe's government became more repressive, authoritative and abusive of human rights. Indeed, there were political, social and economic factors that led to a resumption of the civil war in 1989. Firstly, after the 1985 elections, instead of establishing inclusive democratic governance, Doe deepened ethnic exclusion by disproportionately appointing his own tribe, the Krahns, and co-opted the Mandingoes, who were the wealthiest business people, into his cabinet to the neglect of the rest of the fourteen tribes of Liberia. Secondly, the extra-judicial execution of Colonel Thomas Quinwokpa and his military men, including the Gios and Manos, brought about counter-reaction. Thirdly, the execution of William Tolbert and several members of his cabinet, and the reckless confiscation of property, led the Americo-Liberians to support Charles Talyor's uprising.

From the above account of the factors that led to the civil war in Liberia, it is sufficiently clear that bad governance was the main reason for the violence that followed. As can be seen in Liberia, a crisis of governance as exhibited in the abuse 


\section{Edward Banka Gariba}

of human rights, dictatorial rule, social and ethnic exclusion, and institutional failures led to the overthrow of Doe's government and the turmoil that then engulfed the country. Samuel Doe's regime was very repressive and pursued ethnic discrimination policies. As Amos Sawyer argues, 'Sergeant Samuel Doe ascended to power from the lumpen elements of the Liberian Army. Within a few years, he purged the military of all his rivals and of its trained officers, and relied on an underdisciplined core recruited largely by his Krahn ethnic groups' (Sawyer 2004:444). This means that the professionalism of the military was undermined, and this not only negated merit principles in the military but also weakened the military institution.

The question worth discussing is whether Charles Taylor, after his election in 1997 as the President of Liberia, addressed the socio-economic and political crisis that had led to the civil war. The evidence shows that Taylor failed to address the root causes of the conflict. Instead, leaders of the twelve opposition parties who competed with him in the 1997 elections were harassed and intimidated. This led to a resumption of violent conflict in 1999. The opposition parties went into exile to Guinea and Ivory Coast. It was these exiled groups who formed LURD and MODEL to fight Taylor's government. Indeed, jobs were given to his party supporters, while certain parts of Liberia where his party did not get significant votes were either given no development projects or completely neglected. This led to widespread discontent against the government. The case of Liberia illustrates Nicole Ball's assertion that 'economic and political inequalities form the root causes of conflict in Africa, and until disparities between peoples are reduced, conflict will continue' (Ball 1991:385).

If history is any thing to go by, and surely it is, for history serves as a guide to the future; it enables us to learn from our mistakes and avoid repeating them. That means the current government of Ellen Johnson Sirleaf should address the root causes of conflict (crisis of governance) by pursuing democratic governance and strengthening security policies. What follows is an examination of democratic governance as an antidote to conflict in Liberia. 


\section{Democratic governance as an antidote to a resumption of conflict in Liberia}

Since poor governance has accounted for conflict in Liberia, the pursuit of responsible democratic governance should promote and consolidate peace in the country. As the World Bank (1989:10) notes, 'underlying the litany of Africa's development problems is a crisis of governance. By governance is meant the exercise of political power to govern a nation's affairs'. For Goran Hyden (1999:185), governance is 'that aspect of politics that aims to formulate and manage the rules of the political arena in which state and civil society actors operate and interact to make authoritative decisions. This definition stresses the importance of political government, which is the need for political inclusion, transparency and accountability. Joachim Ahrens (2002:120-128) gives a comprehensive definition of political, economic and corporate governance and stresses the interaction of individual actors, social groups, civic organisations, firms and policy makers to implement and enforce public policies and improve private sector coordination. The United Nations Development Programme (UNDP 1997b:2) defines governance as the exercise of political, economic and social authority in a state.

From the above definitions, the main features of democratic governance are the rule of law, freedom of expression and association, electoral legitimacy, a vibrant media, a responsible civil society, gender equality, transparency, accountability and development oriented leadership. Democratic governance also includes such features as voting, participation, public discourse and judgments, civil society participation and decentralised power. The lack of these features in Liberia undermined the state's capacity and legitimacy to rule, which degenerated into violent conflict.

The crisis of governance lies in the failure of the state to address competing demands by relying on the military, as did Liberia during the Samuel Doe and Charles Taylor regimes, to harass, intimidate torture and silence dissidents. But that approach, like Thomas Hobbes' state of nature, which relies on brute force, grants only temporary relief or breathing space. It achieves negative peace (absence of violence) but does not bring in positive peace (justice, security 


\section{Edward Banka Gariba}

and development). Indeed, as William Zartman (1997:1) rightly points out, 'governing a state is not only the prevention of violent conflicts from destroying the country; it is the continual effort to handle the ordinary conflicts among many groups and their demands which arise as society plays its role in the conduct of normal politics'. Implied in Zartman's argument is that governance is about negotiation and conflict management; it is not about using state military apparatus to coerce and silence dissent, rather than addressing the demands of the various pressures and civil society groups. Thus preventing future conflicts is not solely about keeping rebels away from the use of violence, but is also about establishing accountable, transparent and participatory systems of governance. The resort to coercion is symptomatic of naked autocracy or totalitarianism, and in the long run, this undermines the capacity and legitimacy of the state to govern.

Given the lessons learned in the previous conflicts in Liberia, the post-conflict situation demands a democratic, all-inclusive governance approach. Nepotism, political patronage, rent-seeking, corruption and identity politics which characterised the previous governments should not be repeated. This will require marshalling the necessary political will to address issues such as identity, participation, distribution, penetration and legitimacy (Binder 1991:373). To overcome the crisis of governance in Liberia, it is imperative that these five issues be dealt with. There is a need for the state to provide an enabling political and regulatory environment for civil society to participate in the policy process and decision-making processes either through their representatives in parliament or by grassroots participation.

One of the crucial policy actions required by the Government of Liberia is to endeavour to ensure equitable distribution of resources to benefit all regions, and that is where penetration is important, because a lack of penetration and the concentration of development projects in some regions to the neglect of others lead to marginalisation and regional imbalances. As Stephen Stedman (1995:37) argues, 'conflict resolution is inherently bargaining and problem solving involving the distribution and achievement of shared values'. Governance also requires that leadership be willing to bargain and incorporate the inputs of the various groups into decision making that reflects broad consensus and values. 
Also necessary is the strengthening of civil-military relations in post-conflict Liberia. The military needs to be professionalised, and insulated from political intervention. It is imperative that soldiers are not forcibly retired or dismissed arbitrarily and capriciously by the government in power, but through military discipline and a code of ethics. Nor should the government abuse its power in allowing just one ethnic group to dominate the military. It is sufficiently important that a conscious policy of restraint from the manipulation and politicisation of the ministry be adhered to. Second, there is a need for a civilian regime which legitimises policies that benefit the citizenry, and reflect the democratic values and principles in post-conflict Liberia. As government increases its responsiveness to the social, economic and political demands of the citizenry, its legitimacy in the eyes of the military and its people will increase, diminishing government's vulnerability to violent conflict. Clearly, state legitimacy and adequate capacity are crucial for the maintenance of law and order.

Besides, to consolidate democracy, peace and development in Liberia, the role of civil society is significant. As Stedman (1991:374) argues, 'there is the necessity for democratic reform to reorient state-society relationship so that the political accountability of the rulers is the hub of political life'. The empowerment of civil society will enable them to hold government accountable and ensure transparency. It will also enable civil society to play a watchdog role over the conduct of government to avoid mismanagement of the economy, as well as corruption, political patronage and rent-seeking. To that extent, it is important that civil society has inputs into the policy process, in such areas as the drafting of the national budget and the implementation of policies, development projects and programmes that government pursues. It is important that the tax payers exercise their rights regarding what their monies are used for and how they are used. Indeed, the test of the current leadership and the stability of Liberia will depend on the pursuit of good governance and security policy. What follows now is a discussion of the security policies that will be required to maintain peace in Liberia. 


\section{Edward Banka Gariba}

\section{Security governance in post-conflict Liberia}

The challenges confronting peacebuilders, security experts, interveners and policy makers in a post-conflict country include finding the best way to integrate ex-combatants into either the civilian population or the military. They also have to deal with the disarmament, demobilisation, rehabilitation and reintegration of refugees and internally displaced persons. The whole notion of security sector reform or governance, a term used to describe the transformation of the security system, forms a crucial part of post-conflict development. Without addressing the security dilemma faced by a war-torn state, the prospect of a return to conflict is high.

Security system is defined by the Organisation for Economic Co-operation and Development (OECD) (2004:119) as that 'which includes all the actors, their roles, responsibilities and actions in working together to manage and operate the system in a manner that is more consistent with democratic norms and sound principles of good governance, and thus contributes to a well functioning security framework'. This means that the role of the armed forces, police, paramilitary forces, presidential guards, intelligence services, customs authorities, civil defence forces, civil society, the legislature, judiciary and the executive are keys to promoting the security of the state.

The current President of Liberia faces these enormous tasks. The failure of Charles Taylor's government to formulate any real national security policy following the 1997 Peace Agreement, led to violent conflict in 1999 by exiled Liberians who turned themselves into rebels. Addressing security issues, therefore, becomes crucial in a post-conflict state. A durable peace can be secured in Liberia not only by pursuing political governance of inclusion, but also by pursuing effective security policies that address both state security and human security.

The first policy action required of the Liberian government is a proper disarmament, demobilisation, and rehabilitation of ex-combatants into the civilian population. It is important to collect and dispose arms (disarmament), and to persuade ex-combatants to return all military insignia and renounce military status (demobilisation). But thereafter reintegration becomes essential. 
Without a proper reintegration of ex-combatants into the civilian population, they are tempted to revert to violence. Guns not collected and destroyed at the time of demobilisation will be used in later wars or sold to combatants in other areas. Therefore, 'any place of effective control of small arms must incorporate provisions for the reintegration of ex-combatants into civil society and for the collection and destruction of their personnel weapons' (Klare 2004:130).

Another important policy choice needed by the current President of Liberia is the adoption of a strong national security and defence policy. The current government requires legislation aimed at controlling weapons in the hands of civilians. Indeed, as part of preventing the flow of Small Arms and Light Weapons (SALWs) from circulation in the West African sub-region, there is a need for the current government to re-enact and enforce the National Firearms Control of Liberia Act. This act was introduced in 1956 and it prohibits indigenous Liberians from possessing guns. A broad consultation is needed in the review of the Act to include hunters, traditional leaders, members of parliament, civil society and legal practitioners. Since the Act did not make provision for the collection and destruction of illicit weapons and for the tracking of guns, a new Act should make provision for such measures, as well as a role for the police in arms control and a ban on civilian use of military weapons. Also, tough measures are urgently required on the use and possession of arms, such as issuance of licences, criteria for eligibility to use guns for hunting game, and a ban on the local manufacture of guns.

The composition of the military also needs a reform. The military should not only be ethnically balanced, but should also be professionalised. Government should separate itself from unnecessary interference, while retaining control of the military. Promotion and other issues relating to the military should be dealt with according to the military code of conduct and procedures. Adequate training should be provided to the military on civil-military relationships, on the role of the military in the defence of the state against internal and external aggressions, and on helping the state to promote stability to nurture democratic governance. Ensuring the depoliticisation and professionalisation of the military is needed to promote security reform in a post-conflict country like Liberia. 


\section{Edward Banka Gariba}

Another security policy option to be pursued by the current government is to strengthen internal security which can contain resistance movements and rebel groups from uprising. There are two ways of doing that. One would be to indigenise security in the various communities, which would give local people ownership and power to control and defend their lives. This would require government supporting local communities to train local militias, vigilantes, community watchdog groups and community self-policing groups to augment the work of police and the national army. This would enable local communities to take the responsibility for protecting their lives and property. However, the danger with this policy option is that this power may be misused. Some of these groups may later turn into armed rebels aiming to destabilise the state. The other way is rather to create security desk offices in the various communities and appoint security officers to monitor early warning signals. Early warning is 'information that provides a timely alert to potential conflicts' (Rupesinghe and Kuroda 1992:217). These officers will then collaborate with chiefs and community leaders to set up intelligence security committees to monitor early warning signals about conflict or simmering tensions. It will also involve security officers collaborating with civil society organisations such as non-governmental organisations (NGOs) who work with people at grassroots level and know their concerns and problems. Also, collaborating with religious groups and local networks will be strategically successful in gathering information about existing tensions in the various communities. This will enable security officers to report early warning signals to the government, so it can act decisively on the information to prevent the upsurge and escalation of conflict. Some of the early warning signals to be monitored might be ethnic grievances, information on the possession of small and light weapons by some groups in the community, increased use of protests and demonstrations, citizens' dissatisfaction with government works, complaints of unemployment and the politics of exclusion in the distribution of resources and government appointment. The use of such collaborative monitoring and intelligence gathering on the above issues, coupled with prompt government responses to early warning signals, might prevent internal conflict from arising. 
Closely related to national security, is the need to have a regionalised collaboration of police and customs officers to regulate the movement of SALWs. Given the porosity of borders within member states of ECOWAS, a threat to one member state is a threat to others. The member states of ECOWAS in its Preamble rightly admit that the community 'cannot attain its objectives save in an atmosphere of peace and harmonious understanding. 2 The threats to national security posed by the proliferation of small and light weapons cannot be overemphasised. As Ero and Ndinga-Muvumba (2004:227) rightly argue, 'an estimated seven million weapons are circulating in West Africa ... Efforts at comprehensive disarmament and weapons collection together with initiatives to reintegrate former combatants into local communities can both be undermined by the ready availability of small arms and light weapons. Thus, given the spill-over of conflicts and the proliferation of small arms and light weapons in the West African sub-region, a threat to security of a member state is a threat to all. The maintenance of security becomes crucial if there is to be stability. There is a need for regionalised implementation of the ECOWAS Moratorium on the Importation, Exportation and Manufacture of Light Weapons which was adopted in Abuja, Nigeria, on 31 October 1998. Its purpose is to curb the proliferation of small arms and light weapons by encouraging collaboration and cooperation among national intelligence services, police and customs officers to control the movement of small arms. Regional stability is contingent on the need to reinforce security along the borders of member states to prevent the passage of unauthorised persons or armed groups.

\section{A long-term development approach}

As argued earlier, the literature on post-conflict development/peacebuilding has been concerned with humanitarian assistance in the form of the provision of food, clothing, shelter and medicine by humanitarian relief agencies. It has emphasised, as a short-term development goal, the provision of temporary shelter, and the disarmament, demobilisation and reintegration of refugees, internally displaced persons and child soldiers. These approaches have not been able to guarantee a durable peace. There is, therefore, a need to go beyond

2 See the ECOWAS Preamble 


\section{Edward Banka Gariba}

a short-term development goal to a long-term developmental goal, aimed at addressing illiteracy, poverty, underdevelopment and regional inequalities.

Reintegration in the context of post-conflict development involves two aspects: social reintegration and economic reintegration. The social aspect of reintegration involves healing the wounds of victims occasioned by past human rights abuses. Thus, the social aspects of reintegration will require the Government of Liberia to use the reconciliation process and to encourage religious bodies to address issues with regard to the acceptance of ex-combatants into their communities. This involves persuading offenders to admit to their crimes through the hearings of a Truth and Reconciliation Commission, and for the victims to forgive them for their misdeeds. An alternative would be for the state to institute a retributive justice system in which perpetrators are prosecuted for crimes committed during the civil war. The current government has thus far adopted a reconciliation process. It has also adopted a retributive system for some officials in that Charles Taylor is currently being tried by the International Court of Justice in The Hague for his alleged involvement in crimes against humanity.

On the economic aspects of reintegration, the state needs to provide compensation for those whose properties were confiscated, or who lost relatives. These have been the traditional approaches to reintegration. Though these are necessary, they have been short-lived. I argue that there is a need to pursue a combination of a short- and a long-term development approach that aims simultaneously to address security and development. Because most conflicts exploit short-term dissatisfaction among the populace to initiate conflict, it is imperative for the state to provide short-term jobs or the means of livelihood to all Liberians. However, a long-term development plan is needed to promote sustainable peace and socio-economic development. This can be reached through investment in education by building schools to enable Liberians and ex-combatants to acquire new skills and fully engage in economic activity. Simply forbidding the use of arms does not provide livelihood, and can lead to a return of conflict. Thus, policies are required to promote human security which encompasses survival and the provision of jobs, health care and education. These are the key issues to be addressed by the government that can in the long run address illiteracy, unemployment, poverty and vulnerabilities. This means that peacebuilding is 


\section{Liberia: Governance, security, capacity building and a developmental approach}

a long-term process that requires a developmental approach linking security to development. The reintegration of ex-combatants as well as the provision of jobs to Liberians becomes crucial in the country's strides to stability. Post-conflict peacebuilding is a complex, costly and multi-facetted one aimed ultimately at providing security, development and social rehabilitation through institutional transformation, and tackling the root causes of conflict. It needs to address security challenges under which military, DDR, political, social and economic problems are linked.

Development cannot be achieved without security. At the same time, security is not sustainable without development. There is a synergy of development and security. If developmental problems such as poverty, unemployment, regional inequalities, lack of access to health care and education are not addressed in Liberia, the chances for a resumption of conflict are high. Also, if issues such as the professionalism of the military and the domination of the military by one ethnic group are not addressed and the control of SALWs is not done at the borders and internally, the stakes for opportunistic politicians or greedy individuals to hire rebels from other countries to enter the borders and destabilise the stability of the state are also high. There is, therefore, a need to view security and development issues as interwoven and inextricably linked.

National security policy should aim not only at the attainment of state security but also at addressing development issues. This suggests that post-conflict development requires a long-term development approach which, left to the government of Liberia alone, cannot be possible. It demands more time, commitment and financial support. The support of the international community, donors, NGOs, European Union, ECOWAS, philanthropic organisations and the private sector is needed, if Liberia is to undertake meaningful post-conflict development measures.

The success of Sierra Leone's post-conflict reconstruction has shown that where there is the support of the international community, a lot of progress can be achieved. Sierra Leone received much international support, and the role played by Britain, its former colonial master, during and after the war was tremendous. This implies that if the post-conflict reconstruction in Liberia is to succeed it 


\section{Edward Banka Gariba}

needs tremendous financial support from the United States (US), since Liberia was founded by American descendants (Americo-Liberians), and has been allied to the US since the Cold War era. It also needs financial support from the international community to help reconstruct the state.

\section{Building national capacities}

Liberia has had a functioning government for only five years now. It is still in the post-war reconstruction stage, and capacity building is required to address the poor infrastructural state of public institutions, education, justice, the public sector and the health care system. The UNDP defines capacity building as 'the process by which individuals, organizations, institutions and societies develop abilities (individually and collectively) to perform functions, solve problems, and set and achieve objectives' (UNDP 1997a:3). Capacity building is providing individuals, institutions and organisations with the technical, regulatory, political, social and economic tools to empower themselves. Capacity building in Liberia will need to take place at the national and local levels. At the national level, there is a need for two levels of capacity building to be put in place: one that empowers and improves the skills, capabilities, and competencies of the people put in place to manage the country (politicians, policymakers and public servants in the various ministries); and, secondly, a system of rules and frameworks to guide them in the implementation and management of the affairs of the country. As such, a key priority of the government should be to focus on building leadership underpinned with managerial skills, public service values and ethics, integrity and encompassing national interest, and also administrative and technical capacities at various levels both in the public and private sectors.

Arguably, measures urgently required are: building a strong public ethics commission, establishing the office of an ethics commissioner to investigate complaints of unfairness, conflict of interest, abuse of office and authority, unethical behaviour of public servants and workers in public institutions, and introducing an ethical model to train public servants in virtue ethics of excellence of character and of duty and obligations. Workshops and training must focus on ethical standards, a code of conduct for public officials, and duties and obligations required of public servants and leaders, especially politicians, 


\section{Liberia: Governance, security, capacity building and a developmental approach}

to fulfil their obligations of the state-citizenship contract. In addition, building strong audit institutions to promote transparency and accountability, and a new leadership underpinned with ethics and managerial skills are urgently required to address the massive levels of corruption which led to the prolonged war and the execution of past presidents in Liberia. A key capacity-building effort will be required to strengthen the General Auditing Commission (GAC) of Liberia established in 2005, by recruiting staff with integrity and solid experience and understanding of audit practice. That would increase the independence of the office of the Auditor-General, and enable it to produce quality audits of the country's public institutions and promote accountability and transparency. The 2005 Amendment makes the office of the Auditor-General independent and removes it from reporting to the president of the national legislature. The newly recruited staff needs to be trained in forensic auditing and forensic accounting. Already the GAC has 'a 33 member Forensic Department that has produced 12 quality high profile forensic audits' (Morlu 2010:5), and it should continue in that direction.

In addition, public institutions and ministries need to provide periodic reports such as annual Reports on Plans and Priorities (RPPs) in which strategic outcomes and expected results are linked to resource requirements. Each department should produce Departmental Performance Reports (DPPs) on their achievements related to the commitments set out in their RPPs for feedback by the Public Service Commission, which will then report back to each department about its strengths and weaknesses and suggest areas for improvement. This will promote real management for accountability and actual results for money. The GAC needs to submit its reports and findings to the Public Accounts Committee of the Liberian National Legislature so that those implicated will be brought to the committee for further hearing and action. Strengthening the auditing institutions is needed to put in place proper systems and internal controls to prevent or limit fraud, financial misappropriation, waste and abuse of public resources, and other forms of corruption. This will promote transparency, accountability and the people's trust in the government and confidence in public institutions, which, in turn, will address the democratic deficit and enhance the legitimacy of the government. In addition, the capacity and independence of 


\section{Edward Banka Gariba}

the judiciary needs to be strengthened to enable it to enforce the rule of law, promote human rights, protect contracts and property rights, and to prosecute officials of those implicated in the Auditor-General Report and referred to it by the Public Account Committees for engaging in corruption with impartiality and without fear or favour.

\section{Building local capacities}

Building local capacities to participate in policy formulation, implementation and evaluation is vital if Liberia is to attain socio-economic development and sustainable peace. Building local capacity and ownership will engineer sustainable peace and enhance democratisation and the rule of law in a post-conflict society. The best guarantee of stability is to ensure that people do not only have the capacity to govern themselves, but also have control of the structures put in place to govern. Therefore, strengthening local capability through training and the development of skills to analyse government and local budgets, manage and implement policies, and monitor and evaluate government's programmes and projects is urgently required to enable Liberians to participate in the development process.

It also requires decentralising political, administrative and financial structures to enable local communities to administer their own localities, generate revenues to undertake development, and link local development plans into the national development plan. Given that each community is unique and has its own developmental needs and priorities, it is imperative that they should decide about their own development policies and participate in the decision-making process. Building their capacities thus involves leadership training, technical capacities to analyse budgets and knowledge about the policy processes and institutions of governance. Thus, there is a need for the state and development partners in Liberia to invest in equipping local leadership with institutional and technical capacities to participate in the development process. 


\section{Conclusion}

This article has examined the causes of the Liberian Civil War of 1989-2003 and the policy alternatives that are now available in the country's transitional period to ensure a durable peace and development. It argues that the root cause of the civil war in Liberia was a crisis of governance. By crisis of governance is meant an arbitrary exercise of power (without due regard to the rule of law), authoritarianism, abuses of human rights, the politics of exclusion, the politicisation of the military, inequitable distribution of resources, ethnic discrimination and the suppression of the right to dissent.

It also means the maintenance of the spoils system, a system whereby the ruling government gives government jobs to party supporters as a reward for winning power, and as incentive to keep them in power. This leads to the marginalisation of certain ethnic groups, regions of poverty and inequalities that gradually lead to discontent, revolt and violent conflict. This is what took place during the regimes of Samuel Doe (1980-1989) and Charles Taylor (1990-1999). The case of Liberia, as of many countries in Africa, illustrates the view of Stedman (1991:393) that 'a yawning gap lies in the normative theory of how governments in Africa should act and the explanatory theory of how governments in Africa do act'. This means that the principles of the rule of law, accountability, transparency, independence of the judiciary, press freedom, a robust civil society and a fair distribution of resources, which are the normative principles of democracy, are undermined. As a result, it has led to civil war and the negation of peace and development in Liberia. In this light, there is a need to recognise that democratic consolidation is conditioned by a number of factors (Ayoob 1995:181) as identified by De Nevers (1993:31-32): 'the speed with which ethnic issues are recognized; the level of ethnic tension when the democratization process begins; the size and power of different ethnic groups within the state; the ethnic composition of the previous regime and its opposition; the political positions of the leaders of the main ethnic groups; the presence or absence of external ethnic allies; and the ethnic composition of the military'.

The article makes the case that good governance is the key to addressing the root causes of conflict and to maintaining sustainable peace in Liberia. It 


\section{Edward Banka Gariba}

argues for responsible governance that is participatory, inclusive of ethnic groups, accountable, transparent, and supportive of democratic principles as the equitable distribution of resources and the pursuit of the rule of law. It is also imperative that the state builds strong institutions to strengthen security. These security policies should go beyond mere DDR and include economic reintegration, adoption of a strong national security policy and a regionalised collaboration between police and customs officers to control the proliferation of small arms and light weapons.

More importantly, post-conflict development is more than the temporary cessation of violence, the provision of humanitarian relief and the holding of early elections to enable the exit of peacekeepers and the international community. It is a long-term developmental approach, which requires time and the financial support of the international community and regional actors, to help Liberia undertake the necessary infrastructural reconstruction and the provision of jobs to maintain peace and stability. Thus one cannot but agree with Roger Miller (1992:16) that security and development are so tightly linked that policy makers should move beyond the artificial separation between 'conflict as belonging to the field of security and development as the domain of economics'. There is no denying the fact that enhanced development will promote security. Conversely, the lack of development will trigger insecurity. The policy implication is that security and development are so intertwined that Liberia, like any post-conflict country, should pursue both policies in tandem, if it is to replace conflict through a sustainable peace and prosperous development. It also implies that development policies and programmes should benefit not only the rich but also the poor. It is important that the four pillars of the Liberian Poverty Reduction Strategy Paper launched in 2007, namely (i) Security; (ii) Economic Revitalisation; (iii) Governance and the Rule of Law; and (iv) Infrastructure and Basic Services (Liberia Poverty Reduction Strategy Paper 2008), are vigorously implemented. In particular, the revitalisation of the economy and the provision of infrastructure and basic services need to be implemented to address sanitation and water issues, agriculture and food security and engineer livelihood empowerment for the poor at the rural level. 
Though some of the policy recommendations outlined in this paper are being pursued and implemented by the current government of Liberia, they are not fully integrated into a cohesive comprehensive policy or document. Again, the capacity to implement them is limited and so we need to understand and be reminded that policy development and implementation of policy matter. The current government has been able to pursue DDR policies, which are part of the security reforms. What is left to do is to improve the way in which the military is constituted and professionalised. The Ellen Johnson Sirleaf government has also strengthened relations with member states of ECOWAS and relationships with the West, in particular, the United States of America. The President has, therefore, gained international support in her efforts to reconstruct the state.

President Ellen Johnson Sirleaf has also declared 'zero tolerance' for corruption in line with the good governance approach, and established a Governance and Economic Management Assistance Program (GEMAP) to oversee the economic and political affairs of the state. The main components of the GEMAP include (i) financial management and accountability, (ii) improving budgeting and expenditure management, (iii) improving practices of procurement and granting concessions, (iv) establishing effective processes to control corruption, (v) supporting key institutions, and (vi) capacity building. ${ }^{3}$ However, there is a lack of an integrative security and development framework aimed at addressing underdevelopment, expanding infrastructure, building educational, justice and health systems, and building both national and local capacities to enable Liberians to channel their energies and destinies toward the development of the country. Quite frankly, the relative peace currently existing in the country is fragile. It is only guaranteed by the presence of ' 8,000 soldiers and over 1,000 international police patrolling the country' (Niebel 2011:1). Going forward, the extent to which the Ellen Johnson Sirleaf government is able to address the capacity building hurdles, move beyond pork-barrel politics and political patronage and mobilise Liberians to transfer their ethnic allegiance to the state is key to political stability, peace and development. This is realisable only if the four policy options are pursued and well implemented. If they are not, then Liberia will return to conflict.

3 For a detailed description of the Governance and Economic Management Assistance Program (GEMAP), see <www.GEMAPliberia.org > 


\section{Edward Banka Gariba}

\section{Sources}

Adebajo, Adekeye 2002. Liberia's civil war: Nigeria, ECOMOG and regional security in West Africa. London, Lynne Rienner.

Ahrens, Joachim 2002. Governance and economic development: A comparative institutional approach. Cheltenham, Edward Elgar.

Ayoob, Mohammed 1995. The Third World security predicament: State making, regional conflict, and the international system. Boulder, London: Lynne Rienner.

Ball, Nicole 1991. Cited in Stedman 1991, p. 385.

Binder, Leonard 1991. Crises and sequences in political development. Cited in a chapter entitled 'Conflict and conflict resolution framework', in Deng, Francis and William Zartman eds. Conflict resolution in Africa. Washington, D.C., Brookings Institution Press.

Boutros-Ghali, Boutros 1992. An agenda for peace: Preventive diplomacy, peacemaking and peacekeeping. A/47/277-S/24111. Geneva, United Nations.

Boutros-Ghali, Boutros 1995. Supplement to an Agenda for Peace: Position paper of the Secretary-General on the occasion of the fiftieth anniversary of the United Nations. A/50/60-S/1995/1.

Bush, Kenneth 1996. Beyond Bungee cord humanitarianism: Towards a democratic agenda for peacebuilding. Canadian Journal of Development Studies, Special Issue on 'Governance, Democracy and Human Rights'.

Busumtwi-Sam, James 2004. Development and peacebuilding nexus: Conceptual and operational deficits in international assistance. In: Taiser, M. Ali and Robert O. Matthews eds. Durable peace: Challenges for peacebuilding in Africa. Toronto, University of Toronto Press.

Chesterman, Simon 2002. You, the People: The United Nations transitional administration and state-building. Oxford, Oxford University Press.

De Nevers, Renée 1993. Democratization and ethnic conflict. Survival, 35 (2), pp. 31-48.

Donald, Dominick 2002. Neutrality, impartiality and UN peacekeeping at the beginning of the 21st Century. International Peacekeeping, 19 (4), pp. 21-38.

Ero, Comfort and Angela Ndinga-Muvumba 2004. Small arms, light weapons. In: Adebajo, Adekeye and Ismail Rashid eds. West Africa's security challenges: Building peace in a troubled region. London, Lynne Rienner.

Green, Reginald and Ismail Ahmed 2004. Cited in Busumtwi-Sam 2004.

Hyden, Goran 1999. Governance and the reconstitution of the political order. In: Joseph, Richard ed. State, conflict and democracy in Africa. London, Lynne Rienner.

Klare, Michael 2004. The deadly connection: Paramilitary bands, small arms diffusion, and state failure. In: Rotberg, Robert (ed) When states fail: Causes and consequences. Princeton and Oxford, Princeton University Press. 


\section{Liberia: Governance, security, capacity building and a developmental approach}

Liberia Poverty Reduction Strategy Paper 2008. Available from: <http://www.emansion.gov.lr/ doc/Final\%20PRS.pdf $>$ [Accessed 28 May 2011].

Miller, Robert ed. 1992. Aid as peacemaker: Canadian development assistance and Third World conflict. Ottawa, Carleton University Press.

Morlu, John S. 2010. Goodwill Speech Delivered by the Auditor General of the Republic of Liberia, John S. Morlu, II, on the Occasion of the Centenary Celebration of the Ghana Audit Service.

Niebel, Dick 2011. German official slams Government for 'political corruption'. New Democrat, 20 May 2011.

OECD (Organisation for Economic Co-operation and Development) 2004. Security System Reform and Governance: Policy and good practice. A Development Assistance Committee Reference Document, Paris.

Reilly, Benjamin 2002. Post-conflict elections: Constraints and dangers. International Peacekeeping, 9 (2).

Richmond, Oliver P. 2002. Maintaining order, making peace. Hampshire, NY, Palgrave.

Rupesinghe, Kumar and Muchiko Kuroda eds. 1992. Early warning and conflict resolution. New York, St. Martin Press.

Slim, Hugo 1996. Military humanitarianism and the new peacekeeping: An Agenda for Peace? IDS (Institute of Development Studies) Bulletin, 27 (3).

Sawyer, Amos 2004. Violent conflicts and governance challenges in West Africa: The case of the Mano river. Journal of Modern African Studies, 43 (3).

Stedman, John Stephen 1991. Conflict and conflict resolution in Africa: A conceptual framework. In: Deng, Francis and William Zartman eds. Conflict resolution in Africa. Washington, D.C., Brookings Institution Press.

United Nations 1998. The causes of conflict and the promotion of durable peace and sustainable development in Africa, Report of the UN Secretary-General. New York, United Nations. Para 63 A/52/871-S/1998/318.

UNDP (United Nations Development Programme) 1997a. Capacity Development. Technical Advisory Paper 2. New York, United Nations Development Programme.

UNDP 1997b. Good governance and sustainable human development: A UNDP Policy document. United Nations Development Programme, January 1997.

Uvin, Peter 2000. The development/peacebuilding nexus: A typology and history of changing paradigms. Journal of Peacebuilding and Development, 1 (1), pp. 1-20.

White, Philippe and Lionel Cliffe 2000. Matching response to context in complex political emergencies: 'Relief', 'Development', and 'Peace-Building' or Something In-between? Disasters, 24 (4).

Williams, Michael C. 1998. Civil-military relations and peacekeeping. Oxford, Oxford University Press for the International Institute for Strategic Studies. 


\section{Edward Banka Gariba}

World Bank 1989. Sub-Saharan Africa: From crisis to sustainable growth, A long term perspective study. Washington, D.C., The World Bank.

Zartman, I. William 1997. Introduction. In: Zartman, I. William ed. Governance as conflict management: Politics and violence in West Africa. Washington, D.C., Brookings Institution Press. 